\title{
Det kroniske stressede hastværkssamfund - hvor kommer presset fra, og hvad er konsekvenserne?
}

\author{
Af Preben Melander *)
}

Hvis vi ser os omkring i vort samfund, er der én ting, der springer i øjnene: De fleste mennesker har utroligt travlt. Alle jager afsted, som om de skal nå toget og er for sent på den. Hvis man ikke som bilist overskrider hastighedsgrænsen, bliver man udsat for chikane og nedsættende signaler. Det er desværre blevet en udbredt del af kulturen i vort hverdagssamfund, at vi taler bydende til hinanden. Spørgsmålet er, om det er fornuftigt at bygge et samfund på tidspres og undertrykke omtanke og dybde. Minksagen er et godt eksempel: I det politiske system blev der truffet store samfundsvigtige beslutninger af toppen i stor hast, uden at de ansvarlige tænkte nærmere over, om der var lovhjemmel til at sætte dem i værk.

Hastværkssamfundet har alvorlige konsekvenser for os alle og på alle niveauer. Det fremmer overfladiskhed og ligegyldighed. Hurtige nemme løsninger går forud for seriøse gennemtænkte perspektiver.

Lad os starte analysen nedefra, nemlig med Folkeskolen som case. I en almindelig 5. klasse er der store sociale problemer, som ingen magter og har tid til at tage sig ordentligt af. Relativt mange elever oplever dårlig trivsel og har svært ved at følge med. Flere af pigerne synes ikke, at de har det rigtige udseende og føler sig udenfor. Konkurrencen er hård, og presset fører til øget fravær. Også drengene har psykiske problemer. Flere af den har fået en ADH-diagnose. De har svært ved at sidde stille og koncentrere sig om undervisningen. Mange af lærerne føler sig stresset. De har problemer med at udfolde deres faglighed og samtidig bidrage til at håndtere klassens problemer. Forældrene har tit svært ved at forstå problemernes sammenhæng. De er selv presset af krævende jobs og ofte et forceret familieliv. Man skal jo helst kunne klare flere ting på samme tid, og det er svært i længden. Hæver vi perspektivet til samfundsniveauet, er Folkeskolen udsat for et konstant politisk pres, både oppefra og fra erhvervslivet.

*) Preben Melander er professor emeritus og ansvarshavende redaktør for Samfundslederskab i Skandinavien. 
Der er set over de sidste 20 år iværksat et urimeligt antal reformer i skolens faglige funktioner og den almindelige dagligdag. Skoledagens længde er både blevet udvidet, men sidenhen blevet forkortet igen. Nye evalueringsformer bliver konstant indført, for vi som samfund skal leve op til globaliseringens konkurrencekrav. Endrede internationale testsystemer er blevet afprøvet under politisk pres. De fleste ændringer er indført fra centralt hold og over hals og hoved og uden nødvendig indkøringsperiode. Og alt i alt: Folkeskolen er ikke blevet bedre, men blot mere presset.

Folkeskolen er blot ét blandt flere eksempler på forandringspres og politisk hastværk. Det sker overalt, at der er et samfundspres fra centralt hold, som altid fremstilles som fantastisk, meningsfuldt og nødvendigt, men som set med borgernes optik medfører meningsløse forandringer både for privat- og arbejdslivet. Overalt laves der ændringer i etablerede strukturer, systemer og rutiner, ofte fordi politikkerne og toplederne har et stort behov for at udstille sig selv som handlekraftige og effektive for at opnå karriere. Det kan de så bedst gøre, ved at gennemføre store, synlige og risikable forandringer, der har synlige samfundsmæssige konsekvenser. Som et illustrativt eksempel kan nævnes de store strukturforandringer, som regeringen har gennemført i Forsvaret efter murens fald. Det har medført store besparelser på personel og materiel, som alt i alt har betydet, at det danske forsvar i dag ikke kan forsvare landet uden hjælp udefra. Alligevel fremstår forsvarsministeren som bannerfører i kampen mod pirater ud for Afrikas kyst og som initiativtager til hjælp for Ukraine i en presset situation.

Af andre eksempler kan nævnes de store omlægninger af politiet og retsvæsnet, nedlæggelsen af posthuse og biblioteker, centralisering og omstrukturering af hospitalsvæsenet i flere omgange, udflytning og udtynding af universiteter og uddannelsessituationer etc.

Og dertil kommer en række generelle ændringer i samfundets opgaver og i vores digitalisering, som dagligt medfører ændringer i både offentlige og private organisationers styring og kommunikation med borgerne. Man flytter rundt på folk og deres opgaver uden hensyn til deres faglige relationer og kompetencer, tit i en sådan grad, at både medarbejdere og borgere har svært ved at genkende indholdet og betydningen af kerneopgaverne.

Politikerne og toplederne tror åbenbart, at det er deres opgave at skabe store dramatiske forandringer til gavn for samfundets og menneskers liv og lykke. De burde måske snarere have kæmpet for det modsatte, nemlig at skabe gode og stabile rammer for, at mennesker selv kan indrette deres liv ud fra det, de er bedst til. For mange mennesker lader sig styre af ydre smarte ændringskrav, som ofte senere viser sig at være uden mening og effekt.

Hastværkssamfundets præstations- og systemkrav har store sociale, politiske, menneskelige og økonomiske konsekvenser, ofte langt større end vi i praksis er i stand til at erkende, overskue, og håndtere. Tit bruger vi tid på processer og projekter, som skaber flere problemer, end de løser. Mange forandringer er forårsaget af lederes behov for at demonstrere magt i stedet for at kæmpe for samfundets og organisationers kendte og alvorlige sociale problemer. Overalt i samfundet ser 
man, at det store forandrings- og tidspres resulterer i, at både medarbejdere og ledere har svært ved at leve op til de daglige arbejdsopgaver. De laver flere fejl og har svært ved at levere det, som de selv gerne vil kunne præstere. Deres liv bliver en kamp for at være den, som man gerne vil være. Således føler man skam over, at man ikke kan leve op til hverken ens egne eller omverdens krav. Derfor får mange stress, ofte i en sådan grad, at man bliver alvorligt psykisk syg, og man derfor må vælge at nedtone eller helt forlade jobbet, enten midlertidigt eller for altid. Når stadig flere mennesker går ned med stress, er det en udfordring ikke kun for den enkelte, men for organisationen og hele samfundet. Stress berører derfor os alle. Der findes ikke enkle opskrifter på at undgå, helbrede og leve med stress. Stress er derfor et alvorligt og tiltagende samfundsproblem, som i dag opstår i stort set alle livs- og arbejdsforhold. Det er i dag et udbredt samfundskritisk problem, større end Corona, fordi det er umuligt at vaccinere imod, og der er ingen værnemidler. Det er et problem, som alle taler om, men som kun få føler, at de er i stand til at gøre noget konstruktivt ved. Mange ledere forstår ikke problemets alvor. Man lever blot videre, som om det ikke er ens eget ansvar. "Lev med det", som nogle politikere vil sige, selv om det netop er deres beslutninger, der er årsag til problemerne.

Men hvor kommer mon tids- og præstationspresset fra? Mange har den opfattelse, at det er et alment, socialt og naturligt fænomen, som alle organisationer og samfund har, hvor man skal producere et forventet resultat. Andre mener, at presset er en konsekvens af den styringstankegang, som opstod med Industrisamfundets og teknologiseringens arbejdskultur, der er opstået over de sidste 200 år. Her opstod et organisationssyn, hvorefter alt kunne styres, måles og effektiviseres set ud fra samfundets og markedets økonomiske nyttesyn. Dette måtte mennesker bare acceptere, hvis de ville leve i et moderne produktionssamfund.

Vores menneske- og samfundssyn har heldigvis ændret sig væsentligt set over de sidste 70 år, efter de store sociale, politiske og værdimæssige forandringer, der er sket i Europa siden 1945. Her har man gjort op med Industrisamfundets hierarkiske kontrol og måletyranni, som er afløst af vidensamfundets samskabelses ideer og det demokratiske udviklings- og lederskabelsessyn. Mennesker og samfund er ikke bare maskiner og robotter, der lader sig styre af teknologi og af rationelle systemer, algoritmer og despoters ensporede pres. Mennesker vil gerne kunne se meningen med samfundets værdier og ledelsesudvikling og vil gerne øve indflydelse på samfundets og organisationens sociale og politiske udvikling. Det kan derfor undre, at nogle af vor tids politikere er præget af et materialistisk, instrumentelt og kontrolorienteret styringssyn, der minder om det industrielle kontrolperspektiv fra forrige århundrede. Måske skyldes det, at vor tids politikere, ledere og administratorer alene har fået en forvaltningsuddannelse, som ikke lægger vægt på de etiske, menneskelige og udviklingsmæssige aspekter. Det kan ikke være meningen, at vor tids politikere og ledere har et ledelsessyn, som har rod i forrige århundredes patriarkalske samfund. Det praktiseres stadig i diktaturer som f.eks. Rusland og Kina og breder sig i disse år til resten af 
verden. Udfordringen er, at nogle politikere i disse år synes at prøve at udbrede disse ideer til resten af verden.

I vort samfund prøver politikere i stigende grad at øve indflydelse på vores demokratiske styringsværdier, ikke mindst i den offentlige sektor. F.eks. ser vi som resultat udflytning og udtynding af universiteternes faglige miljøer fra storbyer til provinsen. Det vil i høj grad skade kvaliteten af vores forskning og have en negativ betydning for samfundets konkurrencekraft. Det vil i høj grad ødelægge de forskningsmiljøer, som det har taget en menneskealder at skabe og bringe op på et internationalt niveau. De lader sig ikke retablere, hvis man senere skulle ønske at have brug for dem.

I vort postindustrielle vidensamfund foregår der en politisk kamp mellem på den ene side det rationelle og teknologiske styringssyn og på den anden side det humanistiske og etiske værdisyn. Begge perspektiver bør naturligvis inddrages i samfundets udvikling. Men der synes i dagens digitale udviklingsdebat at være opstået en tilbøjelighed til, at magthaverne fremhæver de rationelle systemorienterede og teknobaserede styringssyn, måske af politiske og populistiske grunde. Dette kan man undre sig over, idet fremtidens komplekse forandringssamfund i høj grad bliver afhængigt af mennesker, der evner at skabe den tværgående åbne kreativitet, udvikle nye perspektiver i videnog lederskabelsen på tværs af grænser og kulturer, og som kan mobilisere vigtige relationer mellem forskellige sociale systemer. Det er her vigtigt, at vore politikere støtter skabelsen af åbne, frie og tværgående faglige udviklingsmiljøer overalt i samfundet.

Det er tankevækkende, at den nuværende regering og med justitsministeren i spidsen opfatter overvågning, kontrol og personregistrering som en forudsætning for borgernes frihed. Det lyder næsten som en politisk tale fra 1930erne, men det er det ikke. Den er fra 2021. Jeg tror, at ministeren blander begreberne tryghed og frihed sammen. Det kan skyldes, at frihedsrettigheder er svære at praktisere politisk i et samfund som vort, hvor frihed ses som en flerdimensionel og sammensat værdi, som politikere tit har svært ved at oversætte til enkle styringsmål. Det er også forklaringen på, at vort gode være- og bæredygtige demokratiske samfund ikke kan skabes oppefra af handlekraftige og ideologiske ledere. Derfor må det frie samfund opsøges og skabes nedefra i en åben dialog mellem selvstændige mennesker, der ikke lader sig styre af ideologier fra toppen. Derimod synes det nemmere at nedbryde og ødelægge et frihedsbasseret demokrati oppefra. Det er der flere despoter og autokrater, der prøver at gøre for tiden. Det er vigtigt, at vi som borgere aktivt kæmper imod disse forsøg. Ellers ender vi som en by i Rusland. 